\title{
EFFECT OF STARVATION ON LH LEVELS IN MALE AND FEMALE HAMSTERS
}

\author{
B. E. HOWLAND AND K. R. SKINNER \\ Department of Oral Biology, The University of Manitoba, \\ Winnipeg, Manitoba R3E OW3, Canada
}

(Received 8th August 1972)

Starvation for more than one oestrous cycle in the hamster has been reported to block follicular development resulting in ovaries with no antral follicles or corpora lutea, but of normal weight (Printz \& Greenwald, 1970). Histological evidence suggested that the maintenance of ovarian weight was due to hypertrophy of interstitial tissue (Printz \& Greenwald, 1970). This response to malnutrition differs from that in the rat where starvation or restricted feed intake leads to a reduction in ovarian weight (Mulinos \& Pomerantz, 1940; Howland, 1972a). In the underfed rat, the reduction in ovarian weight is accompanied by reduced serum levels of LH (Howland, 1971, 1972b). In the starved hamster, however, the hypertrophy of the interstitium was interpreted as evidence for an increase in LH release (Printz \& Greenwald, 1970). Because of this possible species difference in response to undernutrition, the following study was undertaken to determine the effect of starvation on LH secretion in hamsters of both sexes.

The hamsters used in the study were approximately 8 weeks old. Within each sex, they were assigned to a fed or to a starved group. The animals were kept in individual plastic cages in a temperature-controlled $\left(74 \pm 1^{\circ} \mathrm{F}\right)$ and light-controlled ( $12 \mathrm{hr}$ light/12 $\mathrm{hr}$ dark) room and allowed free access to tap water during the experimental period. The males were all started on the experiment on the same day and killed 6 days later. To follow oestrous cycles, the females were observed daily for evidence of a postovulatory discharge. After completion of one normal (4-day) cycle, the animals were placed on treatment for a period of 5 days beginning on the day of postovulatory discharge (Day 1 of the cycle). On the day of autopsy, each animal was lightly anaesthetized with ether, a blood sample was obtained by heart puncture and the animals were then killed with an overdose of ether. The anterior pituitary, gonads and uterus or seminal vesicles were removed and weighed. Pituitaries and serum samples were stored frozen until assayed for LH.

The concentration of $\mathrm{LH}$ in pituitary homogenates and serum of individual hamsters was determined in duplicate using the 0-0 radioimmunoassay described by Niswender, Midgely, Monroe \& Reichert (1968). The results are expressed in terms of NIH-LH-S14. The use of this assay for measuring LH levels in hamsters was reported by Goldman \& Porter (1970). The data were analysed by $t$ test.

The data obtained on males are summarized in Table 1. Starved animals 
lost $27 \%$ of their original body weight compared with a $5 \%$ loss for fed animals. The mean weight of seminal vesicles was lower $(P<0.01)$ in starved animals than in fed animals and testicular weight showed a similar trend $(P<0 \cdot 10)$. Although pituitary weight and pituitary LH concentration were not significantly affected by treatment, the serum LH concentration in starved animals was considerably lower $(P<0.01)$ than that observed in the fed animals.

The reduction in seminal vesicle weights as a result of starvation agrees well with data reported by Negro-Vilar, Dickerman \& Meites (1971) for the

Table 1. Effect of starvation on body weight, organ weights and LH levels in male hamsters

\begin{tabular}{|c|c|c|}
\hline & \multicolumn{2}{|c|}{ Treatment group } \\
\hline & Fed & Starved \\
\hline $\begin{array}{l}\text { No. of hamsters } \\
\text { Initial body wt }(\mathrm{g}) \\
\text { Final body wt }(\mathrm{g}) \\
\text { Seminal vesicle wt }(\mathrm{mg})^{* *} \\
\text { Testicular wt }(\mathrm{g})^{\mathrm{b}} \\
\text { Pituitary wt }(\mathrm{mg}) \\
\text { Pituitary LH concentration }(\mu \mathrm{g} / \mathrm{mg}) \\
\text { Serum LH concentration }(\mathrm{ng} / \mathrm{ml})^{* *}\end{array}$ & $\begin{array}{c}9 \\
92 \pm 4^{\mathrm{a}} \\
87 \pm 4 \\
84 \pm 5 \\
2 \cdot 41 \pm 0 \cdot 08 \\
2 \cdot 4 \pm 0 \cdot 1 \\
4 \cdot 25 \pm 0 \cdot 26 \\
11 \cdot 1 \pm 1 \cdot 5\end{array}$ & $\begin{array}{c}8 \\
96 \pm 5 \\
70 \pm 5 \\
55 \pm 3 \\
2 \cdot 14 \pm 0 \cdot 11 \\
2 \cdot 3 \pm 0 \cdot 1 \\
4 \cdot 60 \pm 0 \cdot 23 \\
3 \cdot 4 \pm 0 \cdot 9\end{array}$ \\
\hline
\end{tabular}

Table 2. Effect of starvation on body weight, organ weights and LH levels in female hamsters

\begin{tabular}{|c|c|c|}
\hline & \multicolumn{2}{|c|}{ Treatment group } \\
\hline & Fed & Starved \\
\hline $\begin{array}{l}\text { No. of hamsters } \\
\text { Initial body wt }(\mathrm{g}) \\
\text { Final body wt }(\mathrm{g}) \\
\text { Ovarian wt }(\mathrm{mg}) \\
\text { Uterine wt }(\mathrm{mg})^{*} \\
\text { Pituitary wt }(\mathrm{mg})^{* *} \\
\text { Pituitary LH concentration }(\mu \mathrm{g} / \mathrm{mg})^{\mathbf{b}} \\
\text { Serum LH concentration }(\mathrm{ng} / \mathrm{ml})\end{array}$ & $\begin{array}{l}8 \\
95 \pm 3^{\mathrm{a}} \\
91 \pm 3 \\
25 \pm 1 \\
217 \pm 15 \\
3 \cdot 7 \pm 0 \cdot 1 \\
0 \cdot 47 \pm 0 \cdot 02 \\
0 \cdot 96 \pm 0 \cdot 13\end{array}$ & $\begin{array}{l}6 \\
98 \pm 7 \\
67 \pm 7 \\
26 \pm 2 \\
135 \pm 26 \\
2 \cdot 5 \pm 0 \cdot 3 \\
0 \cdot 59 \pm 0 \cdot 05 \\
0 \cdot 76 \pm 0 \cdot 09\end{array}$ \\
\hline
\end{tabular}

starved male rat. The reduced serum levels of $\mathrm{LH}$ in starved males without a change in the pituitary concentration of the hormone suggests that its synthesis as well as its release had been impaired. Presumably, the low levels of serum LH in the starved animals allowed a reduction in androgen secretion which resulted in the regression of accessory sex gland weights.

The results obtained for female hamsters are shown in Table 2. Starved animals lost $32 \%$ of their initial weight compared to a $4 \%$ weight loss in fed animals. Starvation did not affect ovarian weight but apparently altered oestrogen secretion as indicated by the lower $(P<0.05)$ mean uterine weight for starved animals compared with fed animals. The expected postovulatory dis- 
charge was observed in all fed animals on the day before autopsy and the ovaries from these animals contained corpora lutea. By contrast, the starved animals failed to show a postovulatory discharge and no corpora lutea were observed on the ovaries from animals in this group. The mean pituitary weight was lower $(P<0 \cdot 01)$ and pituitary LH concentration tended to be higher $(P<0 \cdot 10)$ in starved females compared with their fed controls. The mean serum LH concentration in starved animals appeared to be less than that in fed animals but, unlike the males, this difference was not significant.

The absence of a postovulatory discharge as well as the complete lack of corpora lutea in starved animals indicate that starvation begun on Day 1 of the cycle can completely block the occurrence of the next expected oestrus and ovulation without affecting ovarian weight. These findings are similar to those reported by Printz \& Greenwald (1970), with the exception that their animals, which were presumably older, demonstrated one normal cycle before becoming acyclic. Although we were unable to demonstrate a significant reduction in serum LH levels, it is obvious that the levels in starved animals were not elevated above the levels for Day 2 of the cycle in the fed animals. There is, therefore, no evidence in this study that the maintenance of ovarian weight in the starved female hamster is related to elevated basal serum LH levels.

This study was supported by MRC Canada Grant MA-4454. The authors are grateful to Dr G. D. Niswender, Dr L. E. Reichert, Jr, and the Endocrine Study Section, N.I.H., for supplying materials used in the radioimmunoassay. This work was conducted while one of us (K.R.S.) was receiving a summer scholarship from the Medical Research Council of Canada.

\section{REFERENGES}

Goldman, B. D. \& Porter, J. C. (1970) Serum LH levels in intact and castrated golden hamsters. Endocrinology, 87, 676.

HowzAND, B. E. (1971) Gonadotrophin levels in female rats subjected to restricted feed intake. $\mathcal{F}$. Reprod. Fert. 27, 467.

Howland, B. E. (1972a) Ovarian weight and ovarian compensatory hypertrophy in the rat as affected by duration of underfeeding. F. Reprod. Fert. 28, 321 .

Howland, B. E. (1972b) Effect of restricted feed intake on LH levels in female rats. J. Anim. Sci. 34, 445.

Mulinos, M. G. \& Pomerantz, L. (1940) Pseudo-hypophysectomy. A condition resembling hypophysectomy produced by malnutrition. F. Nutr. 19, 493.

Negro-Vitar, A., Dickerman, E. \& Metres, J. (1971) Effects of starvation on hypothalamic FSH-RF and pituitary FSH in male rats. Endocrinology, 88, 1246.

Niswender, G. D., Midgely, A. R., JR, Monroe, S. E. \& Reichert, L. E., JR (1968) Radioimmunoassay for rat luteinizing hormone with anti-ovine LH serum and ovine LH- ${ }^{131}$ I. Proc. Soc. exp. Biol. Med. 128, 807.

Printz, R. H. \& Greenwald, G. S. (1970) Effects of starvation on follicular development in the cyclic hamster. Endocrinology, 86, 290. 